DOI 10.14746/ps.2015.1.33

\title{
Agnieszka Bryc, Izrael 2020 skazany na potęge?, Poltext, Warszawa 2014, ss. 268.
}

Polityka bezpieczeństwa realizowana przez kolejne izraelskie rządy nie zawsze spotyka się ze zrozumieniem na świecie. Gra interesów prowadzona przez inne państwa w tym regionie dodatkowo nie ułatwia zrozumienia sytuacji, w której znajduje się państwo żydowskie. Bliski Wschód i złożoność problemów tam występujących powoduje, iż poddanie analizie i prognozowanie na temat rozwoju któregokolwiek z tamtejszych państw wymaga od naukowca bogatej wiedzy i umiejętności analitycznych.

To właśnie problematyka polityki zagranicznej i bezpieczeństwa Izraela analizowana jest w monografii Agnieszki Bryc Izrael 2020 skazany na potęgę?. Książka została opublikowana przez wydawnictwo Poltext, a patronat nad nią objęło Centrum Stosunków Międzynarodowych. W ramach struktury tekstu wyodrębniono wprowadzenie i sześć rozdziałów. Co może być interesujące dla czytelnika, klasyczne zakończenie zostało w tej pozycji zastąpione analizą SWOT w opisywanej perspektywie roku 2020. Dodatkowo książkę uzupełniają dwa załączniki zawierające chronologię rządów w Izraelu oraz notki biograficzne premierów uszeregowane w kolejności alfabetycznej.

Już we wprowadzeniu Autorka podkreśla, iż dostrzega zapotrzebowanie na zaprezentowanie bieżących wydarzeń w regionie bliskowschodnim z punktu widzenia Izraela. Argumentuje to ilością napływających niezweryfikowanych informacji, które niejednokrotnie obarczone są błędnymi stereotypami. Ideą tej książki jest bowiem przedstawienie słabych i silnych stron Izraela w kontekście okoliczności międzynarodowych, z którymi musi się mierzyć. Niestety zarówno we wprowadzeniu, jak i w kolejnych rozdziałach Autorka nie thumaczy dlaczego wybrała perspektywę akurat roku 2020.

Pierwszy rozdział książki poświęcony jest uwarunkowaniom polityki prowadzonej przez rząd Izraela. $W$ bardzo treściwy sposób zaprezentowane są w nim informację na temat czynników geograficznych, takich jak: wielkość państwa, kwestie długości granic z poszczególnymi sąsiadami, czy też problem, jaki niesie ze sobą rozproszenie partyjne w Knesecie. To właśnie niewielki obszar, jaki zajmuje państwo żydowskie skłania Autorkę do postawienia tezy, iż jest to główny powód, dla którego kolejne rządy Izraela kładą nacisk na wyprzedzającą strategię militarną. Jak argumentuje A. Bryc, wojna defensywna mogłaby być dla Izraela fatalna w skutkach, choćby z faktu, iż samoloty startujące nawet z Egiptu są w stanie osiągnąć jego terytorium w ciągu jednej minuty.

$\mathrm{W}$ opisie czynników przedstawiono zarówno elementy postrzegane w kategorii hard power, jak i soft power. Czytelnik zapozna się z informacjami na temat działalności i finansowania IDF - Israel Defence Forces. Autorka przedstawia również szacunkowe prognozy finansowania armii do roku 2017. Zainteresować może również zestawienie, w którym porównywane są budżety obronne, populacja, wielkość armii oraz liczba rezerwistów w Izraelu oraz Arabii Saudyjskiej, Egipcie, Iranie, Jordanii, Libanie i Syrii. Sporo uwagi Agnieszka Bryc poświęca również tematyce broni jądrowej w Izraelu. Choć na wstępie tego opisu podkreśla ona, że izraelskie władze nigdy oficjalnie nie przyznały się do posiadania broni jądrowej, to dość precyzyjnie opisuje równocześnie proces, w jakim w rzeczywistości mogły wejść w posiadanie tej broni. Autorka prezentuje również tzw. strategię dwuznaczności, jaką przyjęły wówczas władze w kontekście wypowiadania się na ten te- 
mat. Dostrzega ona też koszty realizacji programu jądrowego - zarówno ekonomiczne, jak i polityczne (tj. przyczynianie się do wyścigu zbrojeń w regionie). Swego rodzaju odpowiedzią na ów wyścig jest również opisany system Iron Dome. Podkreślona została jego 84\% skuteczność w trakcie trwania operacji Filar Obrony, choć równocześnie zauważone zostały gigantyczne koszty z nim związane - niejednokrotnie większe od potencjalnych strat wywołanych przez nieprzechwycony pocisk.

Z pozostałych czynników przeanalizowanych przez Autorkę na uwagę zasługują również kwestie problemów demograficznych w Izraelu, związane z rosnącą liczbą ortodoksyjnych Żydów, co bezpośrednio może mieć wpływ na przyszły podział sił w Knesecie, a co za tym idzie i decyzje polityczne. Czytelnika zainteresować może także opis sytuacji gospodarczej w tym państwie, opartej w dużej mierze o wysokie technologie i zapewniający dość niski poziom bezrobocia (głównie wśród ludności żydowskiej).

Bardzo szczegółowo ukazany został też problem palestyński. Agnieszka Bryc rozpoczyna opis od kolejnych aliji, czyli migracji ludności żydowskiej z powrotem do Palestyny. Kwestia powstania państwa Izrael w 1948 roku i związanych z tym działań wojennych płynnie przechodzi natomiast $\mathrm{w}$ analize powstałej w ich wyniku problematyki palestyńskich uchodźców. Autorka prezentuje między innymi statystyki dotyczące szacowanej liczby ludności palestyńskiej na świecie z podziałem na Izrael, państwa arabskie oraz Zachodni Brzeg Jordanu i Strefę Gazy. Uwagę czytelnika mogą zwrócić jednak informacje przedstawiane z bieżącej sytuacji arabskich mieszkańców państwa żydowskiego. A. Bryc podkreśla bowiem, iż otrzymują oni nieproporcjonalnie mniej funduszy niż wynikałoby to ze struktury demograficznej państwa. Stawia ona również tezę, iż w związku z tym jest to przyczyna wolniejszego rozwoju miast zdominowanych przez ludność arabską, co w dalszej konsekwencji prowadzi do wyższego poziomu bezrobocia i niższego poziomu edukacji. Najważniejszym jednak punktem rozważań Autorki w kontekście relacji izraelsko-palestyńskich jest proces pokojowy i możliwe rozwiązania, które przedstawione są z punktu widzenia Izraela. Za interesujące należy uznać przedstawienie $\mathrm{w}$ formie tabeli zmian pozycji Izraela w stosunku do kolejnych negocjacji z przedstawicielami ludności palestyńskiej.

Osobne rozdziały ukazują miejsce Izraela w świecie arabskim oraz stosunki Izraela z Iranem w perspektywie jego programu jądrowego. W pierwszym kontekście uzyskujemy informację o relacjach państwa Izrael z sąsiednimi państwami arabskimi począwszy od jego powstania. Duży nacisk w tym miejscu położony jest na potencjał militarny obu stron w poszczególnych okresach. Zaprezentowane jest to np. w formie tabel dla sytuacji sprzed kryzysu sueskiego w 1956 roku, czy też w sytuacji wojny sześciodniowej z 1967 roku. Równie dużo miejsca A. Bryc poświęciła zagrożeniom asymetrycznym płynącym ze świata arabskiego. Przeanalizowała bowiem zarówno operację Pokój dla Galilei na południu Libanu i ówczesne ataki OWP, jak i bieżące zagrożenia powodowane działalnością Hezbollahu.

Niebezpieczeństwu związanemu z programem jądrowym Iranu poświęcony został natomiast kolejny rozdział. Co bardzo wartościowe, za punkt wyjścia Autorka obrała przypomnienie czytelnikowi o strategii sojuszu peryferii, do której w latach 50. XX wieku odnosił się jeszcze David Ben Gurion, a która zakładała sojusz Izraela z niearabskimi państwami na Bliskim Wschodzie tj. Turcją i Iranem. Agnieszka Bryc opisuje płaszczyzny, które poróżniły omawiane w tym rozdziale państwa i przyczyniły się do napiętej sytuacji, która ma miejsce obecnie.

W dalszej kolejności analizie poddane zostają relacje państwa żydowskiego z pozostałymi państwami, kluczowymi dla niego w kontekście strategicznym. Autorka zarysowu- 
je między innymi różnicę w polityce amerykańskich administracji G. W. Busha oraz B. Obamy. Wspomniana jest tu dla przykładu nominacja przez tego drugiego dla Chucka Hagela w Departamencie Obrony znanego z wcześniejszych krytycznych wypowiedzi w stosunku do polityki Izraela, ale i również poparcie skierowane ze środowisk żydowskich w USA dla Mitta Romney’a w kampanii wyborczej przeciwko B. Obamie.

Na uwagę zasługuje również analiza relacji z Turcją oraz Indiami. Autorka słusznie zauważyła, że od dojścia do władzy partii AKP i jej lidera Recepa Tayyipa Erdogana, przedefiniowana została polityka zagraniczna Turcji i tylko kwestią czasu było pogorszenie relacji z Izraelem. Tym bardziej, co słusznie zauważyła Agnieszka Bryc, że rząd w Ankarze pretenduje do przejęcia roli swoistego adwokata kwestii palestyńskiej. Ciekawie zaprezentowane zostały również relacje z Indiami, które odwrotnie niż w przypadku Iranu ewoluowały na przestrzeni czasu w pozytywnym dla Izraela kierunku i obecnie oba państwa nawiązują współpracę gospodarczą i militarną.

Ostatnie analizy relacji dwustronnych dotyczą natomiast dwóch państw, które po przemianach tzw. Arabskiej Wiosny w kluczowy sposób oddziałują na politykę bezpieczeństwa Izraela - tj. Egipt i Syria. W pierwszym przypadku, po ponownym dojściu do władzy przedstawicieli związanych z wojskiem, sytuacja, choć nadal pozostaje napięta, to zaczyna być coraz bardziej przewidywalna. W drugim przypadku z kolei, Autorka zauważyła, iż kwestia konfliktu syryjskiego jest nacechowana wielością czynników i interesów. Bardzo dobrze oddaje to dzieląc ten konflikt na 3 poziomy: 1) wewnętrzny, 2) regionalny oraz 3) ponadregionalny, na których kolejno ścierają się interesy: 1) reżimu Bashara Assada z rebeliantami oraz Kurdami, 2) osi szyickiej i sunnickiej w regionie, a także 3) Stanów Zjednoczonych oraz Rosji. To wszystko, jak argumentuje Autorka, nie wpływa pozytywnie na zakończenie konfliktu, a co za tym idzie, ustabilizowanie kwestii bezpieczeństwa Izraela, płynące z tego kierunku.

Jak wspomniano wcześniej, Agnieszka Bryc zrezygnowała z klasycznego podsumowania książki, zastępując je analizą SWOT. W każdym z działów (siła, słabość, szanse i zagrożenia) przedstawione zostały trendy, które powinny być jej zdaniem właściwe dla Izraela w perspektywie roku 2020. Sposób, w jaki zaprezentowane zostało zakończenie, można uznać za esencję całej książki i stylu, w jakim jest napisana. Z bardzo złożonej problematyki, jaką jest kwestia bezpieczeństwa Izraela, a co za tym idzie jego polityki zagranicznej, Autorka wyciągnęła kwestie najistotniejsze i zawarła na 268 stronach książki. Wszystkie czynniki oddziałujące na analizowaną kwestię bezpieczeństwa zostały natomiast przedstawione przez Autorkę w sposób na tyle wyczerpujący, aby zrozumieć punkt widzenia izraelskiej administracji. Było to, jak wskazała Autorka we wstępie, jej głównym celem.

Książka ta powinna stać się obowiązkową lekturą dla studentów stosunków międzynarodowych, którzy chcą poszerzać swoją wiedzę, a w przyszłości specjalizować się w problematyce bliskowschodniej. Tylko zrozumienie motywacji każdej ze stron sporu czy konfliktu w tym regionie może doprowadzić do rzetelnej analizy i wysnucia miarodajnych wniosków. 